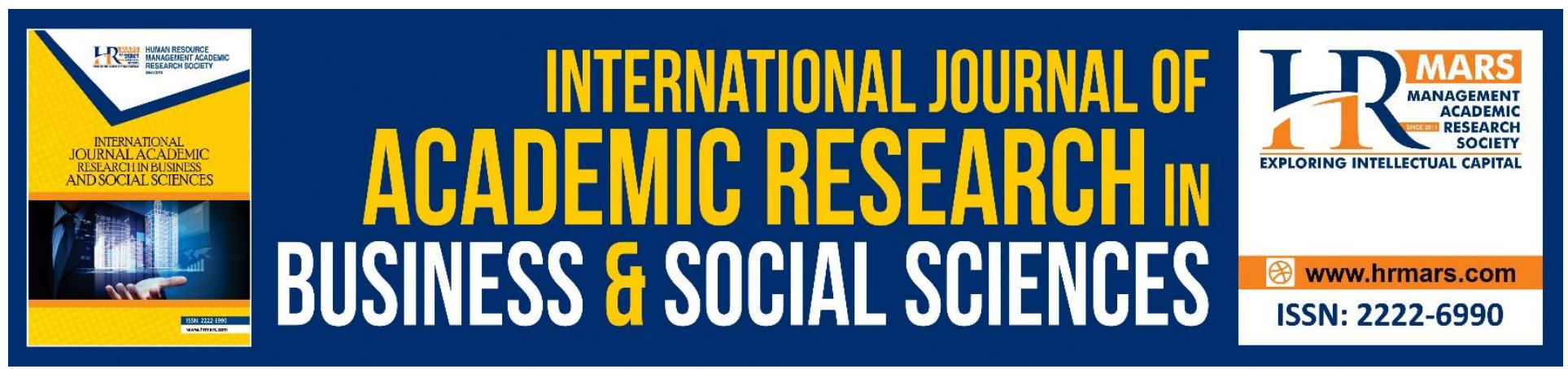

\title{
The Intersection between Strategic Management and Roles of Entrepreneurship: Social Entrepreneur
}

\section{Lovina Yogarajan}

To Link this Article: http://dx.doi.org/10.6007/IJARBSS/v9-i6/5960

DOI: $10.6007 /$ IJARBSS/v9-i6/5960

Received: 16 April 2019, Revised: 19 May 2019, Accepted: 06 June 2019

Published Online: 30 June 2019

In-Text Citation: (Yogarajan, 2019)

To Cite this Article: Yogarajan, L. (2019). The Intersection between Strategic Management and Roles of Entrepreneurship: Social Entrepreneur. International Journal of Academic Research in Business and Social Sciences, 9(6), 407-417.

Copyright: (C) 2019 The Author(s)

Published by Human Resource Management Academic Research Society (www.hrmars.com) This article is published under the Creative Commons Attribution (CC BY 4.0) license. Anyone may reproduce, distribute, translate and create derivative works of this article (for both commercial and non-commercial purposes), subject to full attribution to the original publication and authors. The full terms of this license may be seen at: http://creativecommons.org/licences/by/4.0/legalcode

$$
\text { Vol. 9, No. 6, 2019, Pg. } 407 \text { - } 417
$$




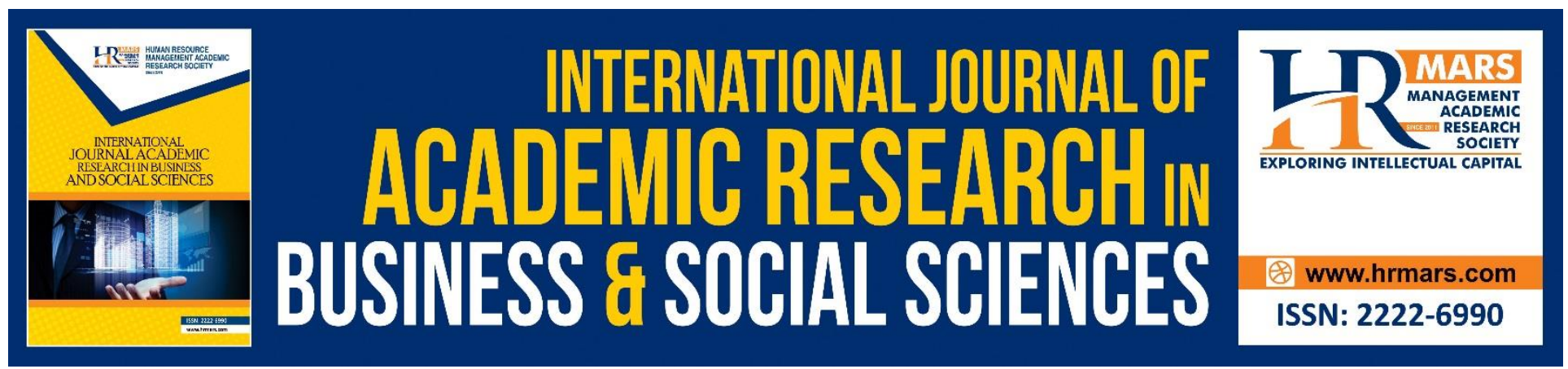

\title{
The Intersection between Strategic Management and Roles of Entrepreneurship: Social Entrepreneur
}

\author{
Lovina Yogarajan \\ Asia Metropolitan University
}

\section{Abstract}

A social entrepreneur is originated from the interaction between strategic management and the role of entrepreneurship, which is referring to the process of building or launching a potential institution to advance solutions to community-based problems. Referring to Bomstein (2004), social entrepreneurs are people with new ideas to address major problems who are relentless in the pursuit of their visions, people who simply will not take "no" for an answer, who will not give up until they have spread their ideas as far as they possibly can. Through all those initiatives, a positive change is developed within social concerns such as wealth creation, a standard of living, community development and environmental destruction. Therefore, entrepreneurs really need to pull their legs in order to conquer societies concerns and apply an effective way to overcome all those circumstances. This concept mainly leads to a positive improvement in society and create a better 'tomorrow' for the community. In this study, a social entrepreneur which is an intersection of an entrepreneur and society is analysed.

Keywords: Social Entrepreneurship, Entrepreneurship, Social, Economic, Entrepreneur

\section{Introduction}

Social entrepreneur significantly referring to how a person's ability to tackle the risk and launch effective efforts to ensure community- based problems settle down. In the concerns, today's society extremely depends on technology to maintain their daily productivity. Based on Boschee (1998) acknowledge that social entrepreneurs are not-for-profit executives who pay interesting attention to market forces without losing sight of their underlying missions, to somehow balance moral imperatives and the profit motives and that balancing act is the heart and soul of the movement. While, the main goal of a social entrepreneur is not to earn the profit, but rather to creates a better or implement widespread improvements in society. So, to be acknowledging that social entrepreneur is describable as a Business to Customer (B2C) strategy applied. Briefly, a social entrepreneur is an intersection of entrepreneur and society and act as a fresh approach in the management review.

The purpose is to show people about how the 7 roles of entrepreneurship which is connected to the strategic management and 5 stages of entrepreneurship have brought out the responsibility of a social entrepreneur. To do so, I have created a new conceptual framework to show the link of 7 roles of entrepreneurship and the 5 stages of social entrepreneurship. This framework allows us to see a 
clear picture of the responsibility of a social entrepreneur. It is important because it influences the degree to which an article's results may be viewed as valid, reliable and generalizable. (Cook \& Campbhell, 1979).

We begin it by explaining briefly what are the 7 roles of entrepreneurship and the 5 stages of social entrepreneurship in order to bring out and explain in detail about the responsibility of social entrepreneur with the proven facts. Finally, I have also offered a few suggestions for future researchers to expand the idea and the theory related to social entrepreneur.

\section{Entrepreneurship}

Entrepreneurship defines the capability and temperament to develop, organize and manage a business venture alongside any of its risks so as to create a profit, the foremost obvious example of entrepreneurship is that the beginning of recent businesses.

In the political economy, entrepreneurship combined with the land, labor, natural resources, and capital will manufacture profit. An entrepreneurial spirit is characterized by innovation and risktaking, an associate degree is a vital part of a nation's ability to achieve an ever dynamic and more and more competitive international marketplace.

Entrepreneurship is that the total of the qualities and activities of someone establishes, and assumes the danger for, a replacement or innovative business venture. Entrepreneurs have special skills and abilities that embrace management skills and provide them a "sixth sense" for business. Those temperament traits and characteristics listed higher than, and imagination, creativity, and long vision will most likely be increased with expertise.

Joseph Schumpeter presented most of his ideas on entrepreneurship in his book The Theory of Economic Development published in 1911(Schumpeter, 1949). Schumpeter opposed the existing views of the entrepreneur as a risk bearer and a manager of a company. Instead, Schumpeter argued that an entrepreneur is an innovator - an individual who carries out one of the following five tasks: (1) the creation of a new good or a new quality; (2) the creation of a new method of production; (3) the opening of a new market; (4) the capture of a new source of supply; or (5) the creation of a new organization or industry (Schumpeter, 1949, p. 66).

\section{The Roles of Entrepreneurship}

Entrepreneurship plays significant role in a country's economic development. Entrepreneurs are the principal movers of innovation. Whereas, an entrepreneur is a person who perceives a business chance and converts it into a viable business set up and so into a business venture ultimately.

Schumpeter first says in his 'The Theory of Economic Development', that entrepreneurship causes economic growth by allowing the means of production in a society to be used in newer and more efficient combinations (Schumpeter, p. 74). Below given the seven most effective roles of entrepreneurship. 


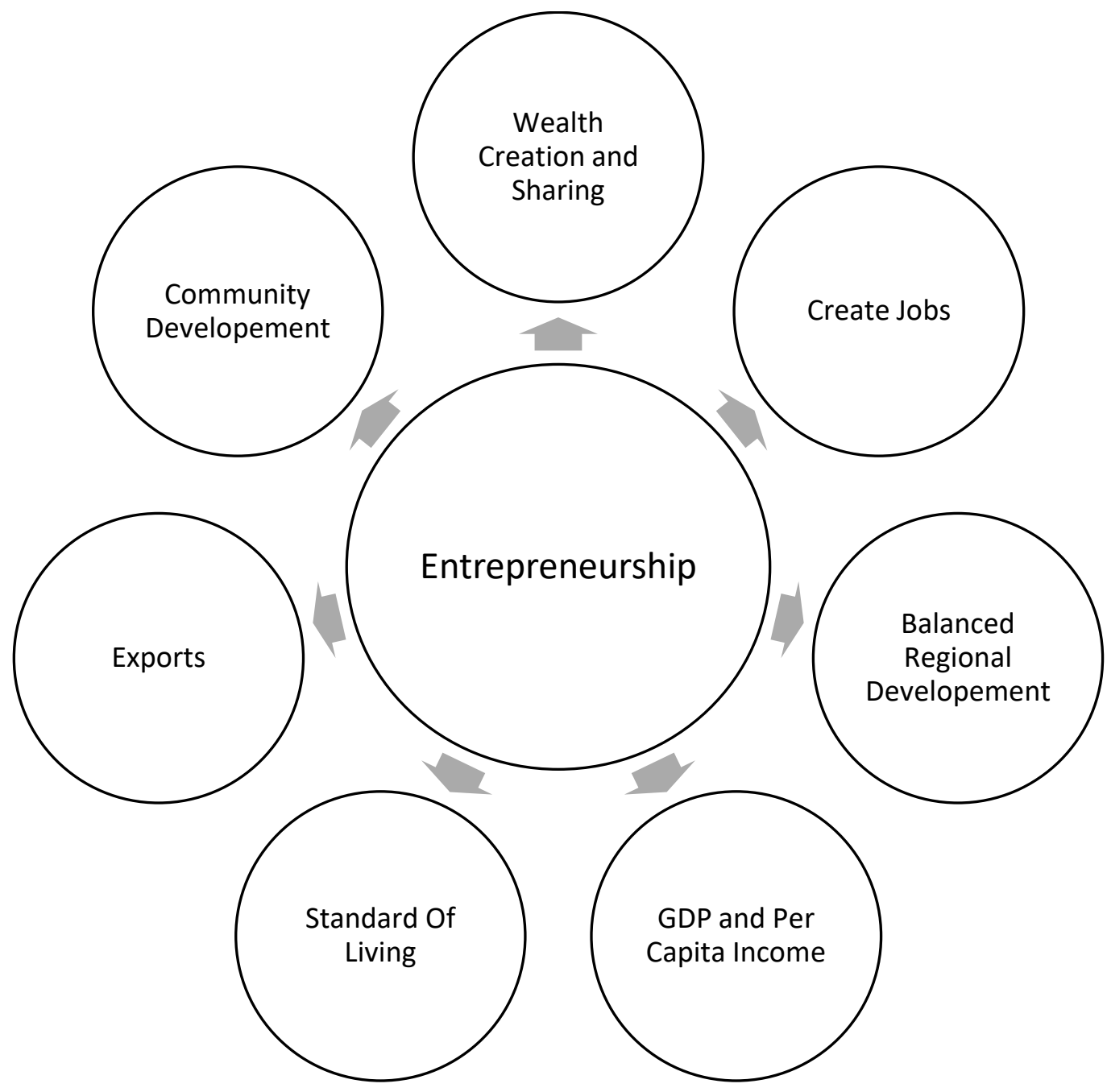

Wealth Creation and Sharing: By setting up business substance, entrepreneurs invest their own resources and attract capital (in the shape of debt, equity, etc.) from investors, lenders and therefore the public. This mobilizes public wealth and permits folks to profit from the success of entrepreneurs and growing businesses. This sort of pooled capital that ends up in wealthcreation and distribution is one among the fundamental objectives and goals of economic development.

Create Jobs: Entrepreneurs are naturally job creators, as opposition job seekers. Once you become an entrepreneur, there is one less job seeker within the economy, and you give employment for multiple alternative job seekers in the society. This sort of job creation by new and existing businesses is usually required in third world countries like in Asia India, Pakistan, Bangladesh and in the African regions where so many unemployed graduates are awaiting for a job.

Balanced Regional Development: Entrepreneurs are establishing new businesses and industrial units facilitate with regional development by placing in less developed and backward areas as mentioned 
before. The development of industries and businesses in those areas drives to infrastructure enhancements preferably roads and rail links, airports, stable electricity and water, schools, hospitals, shopping malls, and other public and private services that will not otherwise be obtainable.

GDP and Per Capita Income: India's MSME (Ministry of Micro, Small \& Medium Enterprises) sector, including of 36 million units that offer employment for more than 80 million people, currently accounts for over $37 \%$ of the country's GDP. Every new addition to those 36 million units makes use of a lot of resources like land, and capital to develop products and services that boost the national income, national product and financial gain of the country. Moreover, this growth in GDP and Per Capita income is one of the fundamental goals of economic development.

Standard of Living: Increase within the standard of living of individuals in a community is yet one more key goal of economic development. Mostly, entrepreneurs play the key role in increasing the quality of living in a community. Additionally, by developing and adopting innovations that results in enhancements in the quality of lifetime of their staffs, customers and gother stakeholders within the community. For instance, automation in manufacturing industries that decreases production costs and enables faster production, which will make a business unit more productive, in the same time also providing its customers with constant product at lower prices.

Exports: Any growing business eventually can expand their business to foreign markets. This is often a very important ingredient of economic development, since it provides access to greater markets and results in currency inflows and access to the most recent stylish technologies and processes being implicated in developed foreign markets. Another key profit that this growth that results in additional business revenue throughout economic downturns within the native economy.

Community Development: Economic development does not forever translate into community development. Community development needs infrastructure for education and training, healthcare and different public services. As an example, you wish extremely educated and versatile staff in a community to draw in new businesses. If there are academic establishments, technical training centers and job opportunities, that may simplify to build the pool of educated and skilled manpower. For that, there is really a vital role for entrepreneurs to spark economic development by beginning new businesses, making jobs, and tributary to improvement in numerous key goals like GDP, exports,skills development and community development.

\section{Five Stages of Social Entrepreneurship}

Alvord, Brown, \& Letts (2004) understand social entrepreneurship creates innovative solutions to immediate social problems and mobilizes the ideas, capacities, resources, and social arrangements required for sustainable social transformation.

Consisted of Five (5) stages of Social Entrepreneurship which acknowledge as a social mission which launch opportunity in solving the social issue and economic value, and the size of social entrepreneurship activity grows based on the stages. 


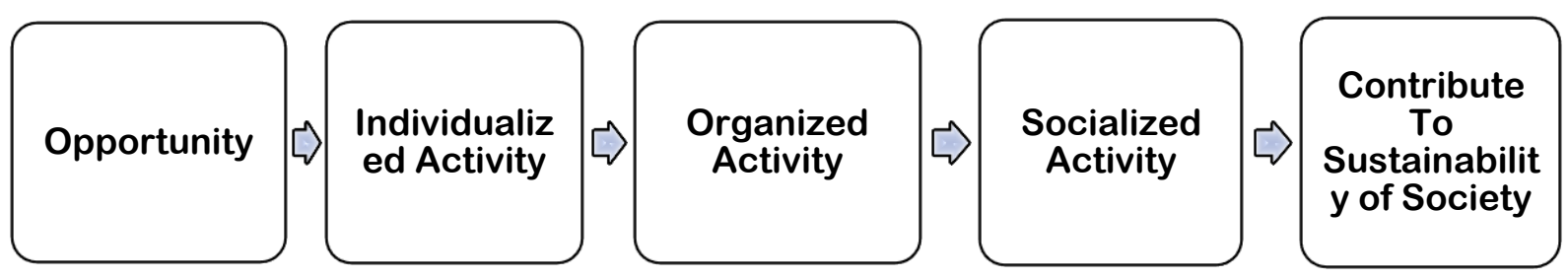

Figure 1: Five Stages of Social Entrepreneurship

Stage 1: Opportunity is to Recognize the Social Issue and to Start Social Entrepreneurship.

According to Kaish and Gilad (1991) entrepreneurship is referring to the process of first, discovering and second, acting on a disequilibrium opportunity and it is clear when it has been define as the attempt to create value through the recognition of business opportunity by Hulbert et al., (1997). An entrepreneurship begins through synonyms including productive thinking, divergent thinking, originality, imagination and lateral thinking Thierauf (1993). So, as referring to a social entrepreneur, they generatean opportunity which includes vision and thought, facts and ideas within the social needs and wants. The golden opportunities creation process are both divides into a social entrepreneur generates a promising idea, and social entrepreneur attempts to develop that idea into an attractive opportunity. An attractive opportunities promise able requires an on-going innovative and creative process working which focused on analysis, experimentation, and some may launch into initial stages of a venture.

\section{Stage 2: Individualized Activity}

Individualized activity refers to which the social entrepreneurship activity is done by a person. In addition, it is a small personalized activity, so it would be difficult to spread rapidly. The social business opportunity is also for an individual; the wage, eventually sustainability is low. The social entrepreneur has been defined as any individual who, with his or her entrepreneurial spirit and personality, will act as a change agent and leader to tackle social problems by recognizing new opportunities and fighting innovative solutions, and is more concerned with creating social value than financial value (Brouard \& Larviet, 2010, p. 40).

\section{Stage 3: Organized Activity}

Social entrepreneurship activity which is organized because of team building or alliance. It starts to spread rapidly with the right staff. Social Business Opportunity gets bigger; the right people hired, trained and Human Resource or Fundraising Strategy executed. 


\section{Stage 4: Socialized Activity}

Social entrepreneurship activity used to solve the social issue by society scale. Mission-shaped people will play a key role in society to realize the Social Entrepreneurship mission. Culture, industry, policy sector will change (Social Change).

\section{Stage 5: Sustainability}

Contribute to the sustainability of society (industry, culture, and policy-making): socialized activity creates outcomes to solve the social issue and contribute to fix our society.So, can be finalized which mission makes it possible to grow Social Entrepreneurship from individualized activity to wellorganized and socialized activity. Alliance with (local) government or policy proposal facilitates Social Entrepreneurship to be a socialized activity. The domain of the public sector, private sector, and citizen sector will be integrated in the future. Social Entrepreneurs are nothing special then. All jobs will pursue a common good.

\section{Social Entrepreneur}

A social entrepreneur is a type of entrepreneur with a social mission. But due to this mission, they will face hard challenges. For social entrepreneurs, the social mission is express and central. This clearly affects however social entrepreneurs understand and assess opportunities. The missionrelated impact becomes the central criterion, not wealth creation Wealth is simply a method to associate finish for social entrepreneurs. With business entrepreneurs, wealth creation may be a means of measurement price creation. This is because business entrepreneurs are subject to plug discipline, which determines in massive half whether they are making the price. If they are doing not shift resources to additional economically productive uses, they have a tendency to be driven out of business.

An entrepreneur's ability to draw in resources (capital, labor, equipment, etc.) in a very competitive marketplace may be a moderately sensible indication that the venture represents an additional productive use of those resources than the alternatives it's competing against. The logic is straightforward. Entrepreneurs who pay the foremost for resources are usually those who will place the resources to higher valued uses, as determined within the marketplace. Price is formed in business once customers are willing to pay over its prices to supply the nice or service being sold-out. The profit that a venture generates may be a moderately sensible indicator of the worth it's created. Markets don't work in addition to social entrepreneurs. Specifically, markets don't do a decent job of valuing social enhancements, public products and harms, and advantages for folks that cannot afford to pay. These parts are usually essential to social entrepreneurship. That's what makes it social entrepreneurship. As a result, it's abundant more durable to work out whether or not a social bourgeois is making adequate social worth to justify the resources employed in making that worth. The survival or growth of a social enterprise isn't proof of its potency or effectiveness in rising social conditions. It's solely a weak indicator, at best. 


\section{Discussion}

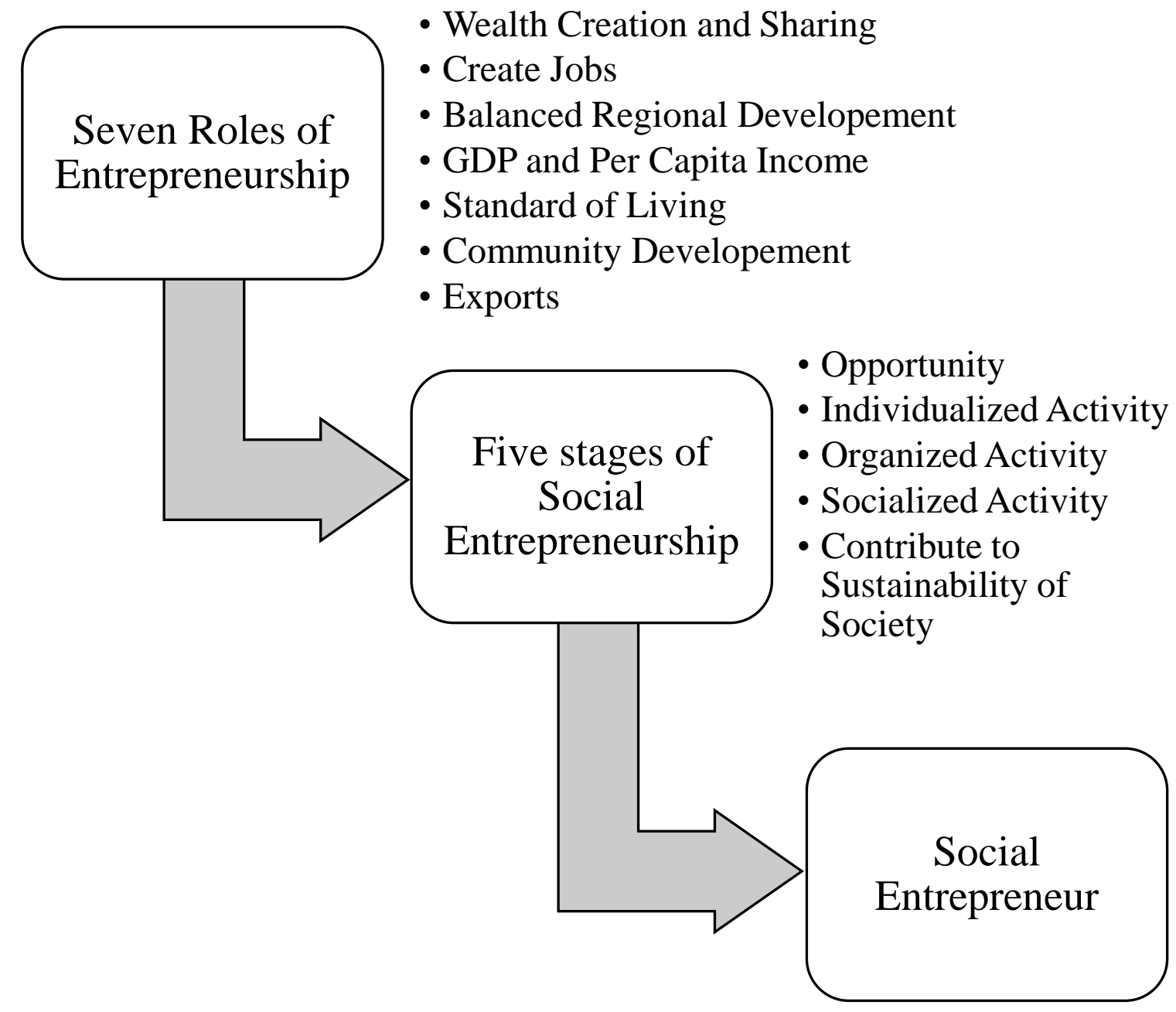

An entrepreneur is well known as national assets to be refined, motivated and encouraged, rewarded and be nourished as well. Entrepreneurs very much important as they the one who act as a first mover and undertakes the risk of the enterprise in search of profit and who's seeking opportunities to profit by satisfying as yet unsatisfied needs. As refers to the norm of entrepreneurs, they are the one who invest and risk their money--and other people's money--to produce a product or service that can result in profit.

Besides, entrepreneurs always seek for disequilibrium which consist of a gap between the wants and needs of customers and the products and services that are currently available. Then only brings together the factors of production necessary to produce, offer and sell desired products and services.The capability of an entrepreneurs should be applaud as they uniqueness of bringing together the money, skilled labour and land or buildings required to produce a product or service, raw materials, manufacturing facilities, and also arranging the marketing, sales and distribution of that product or service. 
The highlight of an entrepreneurs are the trends of an optimistic and future oriented which lead to the believes of the willingness to try various strategies in achieving their goals of profit. Once they succeed of achieving their goals, their revolutions will improve our standard of living and can change the way we live and work.In brief, in expansion to making riches from their entrepreneurial wanders, they too make occupations and the conditions for a thriving society.

Entrepreneurship capital is very important where it launching a huge opportunity on wealth creation and sharing, create jobs, balanced regional development, standard of living, community development, export, GDP, and per capita income. These roles of entrepreneur important in ensuring that social living opportunity is carried well.

The entrepreneurial activities nature's and structures are various across countries as reflected by the relative volumes of necessity and opportunity entrepreneurship. Focuses on which the social entrepreneurship is way to create values through the recognition of business opportunities and an opportunity obsessed, holistic in approach and leadership balanced.

Entrepreneurial are literally generate new wealth, which is also known as wealth creation and sharing. All the existing businesses may stick to the scope of existing markets and hit the glass ceiling in terms of income. When there is a new launch and improved technologies offerings, or products from entrepreneurs, these will helps to enable a new wealth created as new markets are developed. As well as the wealth is created, there would be the existing of an attractive opportunity for community, for example jobs creation and hiring processes increasing in both government and privates sector.

As an additional, the cascading effect of higher earnings and increasing in an employment contributes to a better national income in the form of both higher government spending and tax revenue. The government used this revenue to invest in other, struggling sectors and human capital. The government can soften the blow by redirecting surplus wealth to retrain workers even though it may make a few existing players redundant.

Entrepreneurs are regularly encouraging entrepreneurial ventures by other like-minded individuals. The entrepreneurs also provide financial support to local charities while investing in community projects. This enables further development beyond their own ventures. As an example of some famous entrepreneurs, like Bill Gates, who have used their own asset to launch worth doing, such as education to the level of public health advantages? These qualities will make one entrepreneurs are equal qualities which motivated other entrepreneurs to take it forward.

Here in this review paper, we would like to introduce GMB Akash, who is a documentary photographer and social activist from Dhaka, Bangladesh. By his photography and documentary on the street life cycle of the people of Bangladesh, India and Pakistan, he is creating social awareness and raising fund for them from humanity concerned around the world. He has won over 100 international awards and his work has been featured in National Geographic, Time, Newsweek, The Guardian, and many more well-known publications.

"I am on an endless journey along an infinite route, where I find a real world of humanity. This thirst I have to wander is eternal. I will keep walking, touching every face I drop through my lens. I will show the world those unknown stories of suffering. If my single hand comes to give them shade, that is the real honor of my sweat" - GMB Akash, which is his personal interest in life. 
In his project "Survivors" spans a 10 years period and stretches across Bangladesh, India, Sri Lanka, Philippines, Pakistan and Bhutan. This project focused on the people at the bottom of societies those who are struggling on daily basis, simply to survive.

It is far more difficult for impoverished people to start out a business in rural villages. They don't have space or any idea about how to create and operate a business. Social Entrepreneur GMB Akash is trying to train them and giving them small grocery shops by using part of their home for setting up these shops. These people have no opportunities to earn otherwise. They have had extremely difficult lives. They could not even earn enough to cover their daily expenses. Now every day they can earn $300 / 400$ taka. They receive an idea, motivation and the training from him after surveying their market to see what products might be in demand. He is buying all of the building materials, stocks and then start-up these grocery shops for them.

"Our Small gestures can bring light into the dark places of this world." - GMB Akash

However, by sharing his photography, he is creating social awareness to the people around the world, raising fund for the people and sharing it to them who are under poverty line in the Indian subcontinent by producing income source with the amount. By following his mission the unemployed graduates in this region are getting attracted and inspired to street photography and social work.

\section{Conclusion}

Based on the discussion that has been explained, I believe strongly that the roles of entrepreneurship and the stages of social entrepreneurship have brought great value and a sense of responsibility which has created an awareness towards the public and the environment. This highlights the roles of a realistic social entrepreneur.

Ultimately, if the government and the people of these countries also give support for the venture of the social entrepreneurs, we can see a balanced regional development, boosted GDP and Per Capita income. And at the end slowly but steadily standard of living will increase and we will get community development.The issues of the world are great, and the capability of authorities and the non-public area on my own to resolve them are limited. That said, it would be beneficial for those currently engaged in or attracted to social entrepreneur to seem extra intently at the achievements and successes of their predecessors, with an eye to figuring out who and/or what used to be responsible for these successes. Indeed, solely thru such rigorous evaluation will the subject increase a better perception of the kinds of troubles social entrepreneur is specifically properly suited to address, as nicely those it needs to go away to others. And that is in everyone's excellent interest.

\section{Suggestion for Future Research}

As the field of social entrepreneurship grows, future researchers should pay more attention on how social entrepreneurship is related to the roles of entrepreneurship. This will be the integral route to achieve sustainable development goals when approaching the year of 2030, as community development is one of the essential criteria in the roles of entrepreneurship. Based on the global challenges that we face including poverty and inequality, social entrepreneurship will emerge as a pathway to solve these issues. Besides, of improving the social development, future researchers can 
INTERNATIONAL JOURNAL OF ACADEMIC RESEARCH IN BUSINESS AND SOCIAL SCIENCES

Vol. 9, No. 6, June, 2019, E-ISSN: 2222-6990 (C) 2019 HRMARS

also use the 7 roles of entrepreneurship and the five stages of entrepreneurship to improve economic growth and environmental protection.

\section{References}

Seelos, C., \& Mair, J. (2005). Social entrepreneurship: Creating new business models to serve the poor. Business Horizons, 48(3), 241-246.

Kummitha, R. K. (2016). Barefoot as a Social Enterprise. Social Entrepreneurship and Social Inclusion, 135-160.

Mesure, H. (2008). Creating a World Without Poverty: Social Business and the Future of Capitalism20084Mohammed Yunus and Karl Weber. Creating a World Without Poverty: Social Business and the Future of Capitalism. Cambridge, MA: Perseus Publishing 2007. 261 pp. 658 words. Society and Business Review, 3(2), 176-177.

Kaish, S., \& Gilad, B. (1991). Characteristics of opportunities search of entrepreneurs versus executives: Sources, interests, general alertness. Journal of Business Venturing, 6(1), 45-61.

Brouard, F., \& Larivet, S. (n.d.). Essay of Clarifications and Definitions of the Related Concepts of Social Enterprise, Social Entrepreneur and Social Entrepreneurship. Handbook of Research on Social Entrepreneurship.

Carman, J. G. (2009). The Accountability Movement. Nonprofit and Voluntary Sector Quarterly, 39(2), 256-274.

Dacin, P. A., Dacin, M. T., \& Matear, M. (2010). Social Entrepreneurship: Why We Dont Need a New Theory and How We Move Forward From Here. Academy of Management Perspectives, 24(3), 37-57.

Dobrev, S. D., \& Barnett, W. P. (2005). Organizational Roles and Transition to Entrepreneurship. Academy of Management Journal, 48(3), 433-449.

Certo, S. T., \& Miller, T. (2008). Social entrepreneurship: Key issues and concepts. Business Horizons, 51(4), 267-271. 